\title{
American Strategic Communication in Iraq: The "Rapid Reaction Media Team"
}

\section{James Pamment, Stockholm University, Sweden}

\begin{abstract}
The purpose of this paper is to interpret an American military media strategy designed for the Iraq war from a perspective drawing on recent theoretical discussions of space and time. The material consists of a short white paper that was declassified under the Freedom of Information Act and published by the NSA in 2007. It outlines a 'Rapid Reaction Media Team' which was tasked with designing and implementing the US-led media system at the onset of war in March 2003. Despite aiming to create a 'balanced and fair' public service television network equivalent to the BBC or PBS, the $\$ 100$ million budget was derived from the $\$ 87.5$ billion military budget, with the Department of Defense overseeing implementation. Hence there was a fundamental contradiction between the stated intentions of the network as a provider of balanced news and its broader position within US military objectives. The RRMT plan reveals a series of strategies, inherent conflicts, and assumptions which can be seen to enact forms of symbolic violence complimentary to that of the military. By this, I mean that it sheds light on sophisticated strategies for the 'transposition' of military force to the discursive sphere; for the exertion of violence by other means in US attempts to manage perceptions of the war. In a fundamental sense, the RRMT strategy uses media as an extension of warfare, and this paper will look at how 'actual' violence was transferred from the military battlefield to the discursive.
\end{abstract}

\section{Introduction}

The purpose of this paper is to interpret an American military media strategy designed for the Iraq war from a perspective drawing on recent theoretical discussions of space and time. The material consists of a short white paper (3 pages) and accompanying PowerPoint presentation that were declassified under the Freedom of Information Act and published by the National Security Archive in 2007. They outline a 'Rapid Reaction Media Team' (RRMT) which was tasked with designing and implementing the US-led media system (the Iraqi Media Network) 
at the onset of war in March 2003. The IMN was to comprise of 24-hour satellite news channel, two terrestrial tv channels, two radio channels, a national newspaper, and regional production facilities. Despite aiming to create a 'balanced and fair' public service television network equivalent to the BBC or PBS, the IMN's \$100 million budget was derived from the $\$ 87.5$ billion military budget, with the Special Operations and Low-Intensity Conflict division of the Department of Defence overseeing implementation. Hence there was a fundamental contradiction between the stated intentions of the network as a provider of balanced news and its broader position within US military objectives.

This fundamental contradiction between the needs of a free, democratic media and those of an occupying power lies at the heart of my analysis. The RRMT documents highlight a plan (or what Henri Lefebvre might term a 'conceptual space') for how Iraqi media was to be established in the early weeks of the war as both a propagandist mouthpiece and symbol of the new Iraq. Although it remains unclear how closely the outline was actually followed in practice, analysis reveals a number of wider issues relating to the role of media in contemporary warfare. The RRMT plan reveals a series of strategies, inherent conflicts, and assumptions which, when interpreted from a critical spatio-temporal perspective, can be seen to enact forms of symbolic violence complimentary to that of the military. By this, I mean that it sheds light on sophisticated strategies for the 'transposition' of military force to the discursive sphere; for the exertion of violence by other means in US attempts to manage perceptions of the war. In a fundamental sense, the RRMT strategy uses media as an extension of warfare, and this paper will look at how 'actual' violence was transferred from the military battlefield to the discursive.

The spatio-temporal perspective I employ draws upon two bodies of research. The first is that of the so-called spatial turn in media studies, which takes influences from primarily Anglophone cultural geography ${ }^{1}$. The second relates to some of the sociologists who act as sources for this more recent 'turn' and includes authors such as Henri Lefebvre, Johan Galtung, and David Harvey. The term 'space' in this usage encompasses the material (technological, infrastructural) and discursive (contents) elements of media and how they relate to one another in a holistic sense. As Harvey puts it, 'Processes that so revolutionise the objective qualities of space and time that we are forced to alter, sometimes in quite radical

\footnotetext{
${ }^{1}$ See for example Couldry \& McCarthy, 2004; Falkheimer \& Jansson, 2006
} 
ways, how we represent the world to ourselves'2. Much of my analysis assesses the interaction between military force, the implementation of media infrastructure, and how the contents permitted by these structures 'produce' an abstracted Iraqi space. I consider this space to be both discursive and material, insofar as technology and infrastructure (satellites, televisions, cables, electricity, access to production and distribution) contribute to the formation of discourse - and to its practice in material circumstances. In addition to this theoretical framework, I have drawn on a number of articles and books relating to strategic communication and the war in Iraq, examples from which are used to place the RRMT plan in a wider, more dynamic context of international flows of information and struggles over meaning.

I first introduce three strategic communication paradigms related to state interaction with publics: public affairs, Information Operations, and public diplomacy. In the second section, I take up some important issues related to modern state communication, including symbols of the national interest, counter-flows of information, and the transposition of military power into communicative spheres. In the third part, I look more closely at the objectives, programming strategies, and outcomes of the RRMT.

\section{Communication paradigms}

Public affairs refers to political communication from governments to domestic media, usually through press conferences and official releases. For example, a study of 414 news stories on Iraq from ABC, CBS and NBC between September 2002 and February 2003 found that all but 34 stories originated from the White House, Pentagon, or State Department ${ }^{3}$. An NGO called the Iraqi National Congress (INC) created by the CIA and the Department of Defense soon after the Gulf War was the source for over a hundred articles on Iraq published by US media between October 2001 and May 2002 ${ }^{4}$. The United States government (henceforth USG) made use of the domestic news industry to promote (or 'sell') the war with this form of strategic communication among others ${ }^{5}$. Techniques from advertising, marketing, public

\footnotetext{
${ }^{2}$ Harvey 1990, p240

${ }^{3}$ Snow \& Taylor 2006, p403; the original study was carried out by media analyst Andrew Tyndall, see http://tyndallreport.com/

${ }^{4}$ Kennedy \& Lucas 2005, pp319-320.

${ }^{5}$ There are a number of books detailing this, for example Miller, 2004. I am aware that the term USG glosses the interaction between individuals and departments. Although this paper at times refers to different government
} 
relations, and branding have heavily influenced public affairs, thus binding its practice to private industries at many levels. Furthermore, its narrow definition as communication with domestic audiences is complicated by global news networks picking up American news stories and vice versa ${ }^{6}$.

Information Operations are military-led exercises with the aim of 'shaping the information space' or 'perception management'. They may include straightforward information campaigns (such as information about landmines), 'psychological operations' (PSYOPs), and propaganda and deception ${ }^{7}$. An example can be seen in the opening phases of Operation Iraqi Freedom, during which a 'barrage' of broadcast messages, emails, faxes, and cell phone calls were sent to numerous Iraqi leaders urging them to abandon support for Saddam ${ }^{8}$. Estimates suggest that between 31 and 36 million information leaflets of different kinds were dropped on Iraq by coalition forces during the first phase of the war. Of the 60 different types of leaflets, $40 \%$ of the messages urged surrender of troops under threat of violence, and $30 \%$ related to civilian protection and information ${ }^{9}$. Since these military communication exercises were bound to more general military activity, the strategy could be defined as communicative acts by the military backed up by the threat of violence.

Public diplomacy takes influences from public affairs but is government communication aimed directly at foreign publics. This involves a decentring of diplomatic practices from between governments and behind closed doors, to strategic engagement with foreign citizens, and particularly those in positions of influence. Examples include education and cultural exchanges (Fulbright scholarships), non-military broadcasting (Voice of America, Radio Free Europe, Hollywood), and publications in different languages designed to inform about American history and culture ${ }^{10}$. More advocacy-oriented examples include having articles from leading politicians translated and published in foreign newspapers, political lobbying in the popular media and initiatives designed to boost bilateral trade. One aim of such strategies

departments, I primarily use the term 'state' to broadly denote difference to private industry. This is a necessary limitation of the study.

${ }^{6}$ Brown 2003, p90; Defense Science Board 2004

${ }^{7}$ Taylor 2003, pp103-104; Wilson, 2006. Other Information Operations areas defined by the Department of Defense include Computer Network Operations (CNO) and Electronic Warfare (EW).

${ }^{8}$ Wilson 2006, p3

${ }^{9}$ Clark \& Christie 2005; Friedman 2003, p10. The rest were specific messages about oil, WMDs, and liberation (i.e., general propaganda).

${ }^{10}$ Epstein 2006, pp6-7; Kennedy \& Lucas 2005, pp311-312 
is to put pressure upon foreign governments by directly influencing the opinions of their electorates. Critics contend that this involves undermining the sovereignty of governments from below, with US strategies ignoring borders in other territories while vigorously asserting its own ${ }^{11}$.

Both policy makers and historians associate the 9/11 attacks with a failure on the part of the US to recognise the importance of public diplomacy after the end of the Cold War, a decline which culminated with the abolition of the U.S. Information Agency (USIA) in 1999. Since 9/11, public diplomacy has been considered an important method for defining the purpose of the War on Terror and engaging the middle ground of public opinion around the world against extremism $^{12}$. Examples of public diplomacy in the Middle East include interviews with Arabic-speaking State Department officials on al-Jazeera, the purchase of $\$ 15$ million worth of airtime for the promotion of Muslim-American lifestyles ${ }^{13}$, and ' $H i$ ', a short-lived Arabic language, teen-oriented lifestyle magazine. However, the tendency has been to perceive open dialogue, particularly when the framing and wording of the dialogue goes against US policy, as a direct threat to American objectives. This fear has seen military, rather than State Department, communication characterise American approaches to the region, even though it often - misleadingly - takes place under the banner of 'public diplomacy'. The RRMT plan sits rather awkwardly at the intersection of IO and public diplomacy activities, representing both part of the war effort and a putative Iraqi public sphere.

\section{Communication issues}

Before moving on to an analysis of the RRMT text, it is worth raising three important caveats and further issues relating to these definitions. The first is the role of the state in managing the national brand, and the influence of PR, marketing, and branding strategies on political communication. The second looks at 'spatial anomalies' in the definitions of domestic and foreign publics, and in particular inter- and counter- spatial flows of information. The third

\footnotetext{
${ }^{11}$ Nakamura \& Epstein 2007, pp5-12 \& 20-21. The US has a Foreign Agents Act which requires companies promoting foreign nations in America to register.

${ }^{12}$ Epstein 2006; Snow \& Taylor 2006, p394; Kennedy \& Lucas 2005, pp317-319; Svet 2006, pp5-9; see also the 9/11 Commission Report

${ }^{13}$ The so-called Shared Values Initiative featured 30-60 second advertisement slots of a baker, doctor, teacher, journalism student, and firefighter talking about their lives; Kendrick \& Fullerton 2005, pp8-9; Kennedy \& Lucas 2005, pp318-319.
} 
discusses the interaction and transference of force between hard and soft power, particularly in relation to journalism in Iraq.

Symbolising the national interest

Theories of the enabling and competitive state note that a central contemporary state role is the support of 'enterprise' and the 'competitiveness' of industries based in the state. Modern states enable and encourage, acting as facilitators and conduits for inwards and outwards investment ${ }^{14}$. This designates the state as assuming the role of 'manager' of the 'national interest' within a loose, often contradictory, collaboration with industries over the expression of those interests. A national brand can be seen in (i) the national context as values and common objectives that symbolise the binding of different public and private entities into a common purpose; as well as (ii) in an international sense of dialogues and practices that build on specific values associated with nations and their national industries ${ }^{15}$. From this perspective, Brand USA 'is not itself the primary brand, but the manager of a series of related sub-brands (its arts, sports, media and technology, as well as its foreign policy) ${ }^{16}$. This blurs 'not only the boundaries of information, culture, and propaganda, but also the boundaries of state and private identities and actions, ${ }^{17}$.

The close nature of this relationship is strongly implied by those critical of the execution of the War on Terror. Some scholars maintain that the original mandate for cultural diplomacy as it evolved in the late 1940s and early 1950s 'paralleled and even influenced the formation of a "national security state" created both to devise and pursue a "total" strategy abroad"18. They argue that the term military-industrial complex, associated with Keynesian rational economics and the early Cold War, has evolved into a twenty-first century military-media complex or military-industrial-media complex ${ }^{19}$. Charlotte Beers, former chairman of advertising agencies J. Walter Thompson and Ogilvy \& Mather, was made Under Secretary of State for Public Diplomacy and Public Affairs between October 2001 and March 2003. Such relationships between Madison Avenue, broadcast and news networks, and governments have

\footnotetext{
${ }^{14}$ Cameron \& Palan 1999, p180; Mann 1997, p145

${ }^{15}$ Fisher \& Bröckerhoff 2008, pp12-19; van Ham 2003, pp433-434.

${ }^{16}$ van Ham 2003, pp429 \& 433

${ }^{17}$ Kennedy \& Lucas 2005, pp314-315

${ }^{18}$ Kennedy \& Lucas 2005, p311

${ }^{19}$ Altheide \& Grimes 2005, p621 and Snow \& Taylor 2006, p401 respectively; see also McCormick 2005, pp473-475 for more on the 'interlocking structural relationships' between corporate and political elites from the Eisenhower era to the W. Bush administration.
} 
been seen as 'mutually exploitative', based on close long-term working relationships and common interests ${ }^{20}$. This perhaps met its extreme when some US television news journalists, early on in the war, wore 'flag pins in lapels, occasionally crying on camera, and offering constant moral support' to troops ${ }^{21}$.

While the notion of the competitive and enabling nation-state is useful for highlighting the temporary intersections between state, industries, symbols of national unity, and common interests, it tends to simplify these processes. As a 2004 report noted, many of the problems of Bush-era public diplomacy were embedded in the institutions and in particular in a lack of clear leadership and strategy for communication work $^{22}$. The lobby group Business for Diplomatic Action (DBA), created in 2004, argues that business can perform a role in public diplomacy activities, a position which suggests the collusion thesis is exaggerated ${ }^{23}$. Although there may be intriguing instances of close working between certain elements of state and private industries, I argue here that it is a lack of coordination, both within government departments and between government and industry, which by and large characterises the context in which the RRMT project was carried out.

\section{Spatial anomalies}

The 'spatial' boundaries between domestic and foreign publics are unstable, which problematises the conceptual distinction between public affairs and public diplomacy. For example, following an exposé in the New York Times in February 2002, Pentagon plans to establish an Office of Strategic Influence (OSI) designed to disseminate news to foreign publics came to a premature end amid accusations that disinformation intended for foreign media could end up as sources for American news agencies ${ }^{24}$. American audiences are constitutionally protected from being the subjects of government propaganda under the Smith-Mundt Act. The boundary between foreign and domestic markets has given way to a series of complex interrelations which render the intentions of strategic influence spatially ambiguous. Meanwhile, Arab satellite broadcasting networks Al-Jazeera and Al-Arabiya have influentially challenged Western depictions of conflicts in the Middle East, while shaping new

\footnotetext{
${ }^{20}$ McCormick 2005, pp509-512

${ }^{21}$ Altheide \& Grimes 2005, pp629-630

${ }^{22}$ Defense Science Board, 2004. A formal national strategy for public diplomacy was only published in 2007; see PCC 2007

${ }^{23}$ Business for Diplomatic Action, 2007; Mueller 2009, pp106-107

${ }^{24}$ Snow \& Taylor 2006, pp399-400; Taylor 2003, p105; Kennedy \& Lucas 2005, pp319-320.
} 
media spaces within the region and among diasporas in the $\mathrm{West}^{25}$. Worldwide and regional flows of news thus offer both opportunities and hazards for strategic communication.

An example of these spatial ambiguities can be seen in the rise in blogging, mobile phone photography, and the so-called YouTube Effect ${ }^{26}$. USG attempts to manage the image of the war have been undermined not just by al-Jazeera journalists but also by soldiers' own productions of images. Clips depicting violence and cruelty have been filmed by military personnel and uploaded to public websites such as YouTube and NowThat'sFuckedUp.com, thus countering military-sanitised images of bloodless fire-fights, video game-type 'surgical' operations, and feel-good interactions with Iraqi civilians ${ }^{27}$. Although the authenticity and sources of these clips should not necessarily be taken at face value, they underscore the difficulty of managing information flows during the present phase of mobile media, particularly in light of the temporal (almost instantaneous uploading and long-term availability) and spatial (produced with mobile technologies and accessible in principle from anywhere in the world) aspects of these media.

Converting military dominance into ideological dominance

Military communication makes explicit the connection between excess of force (i.e., military superiority) and the need to express that force in other means, for example through communication. For Johan Galtung in the early 1970s, 'military imperialism can easily be converted into communication imperialism', and power can be relatively straightforwardly 'converted' across economic, cultural, political, and communicative spaces ${ }^{28}$. However, it is telling that American international relations experts in the post-Cold War era focused on problems of exerting influence across and between such spaces. Joseph Nye (of 'soft power' fame) laments the fact that dominance of one key strategic sphere does not immediately guarantee supremacy in all others. He claims that 'the fragmentation of world politics into many different spheres has made power resources less fungible, that is, less transferable from sphere to sphere'. He continues, 'if military power could be transferred freely into the realms of economics ... the overall hierarchy determined by military strength would accurately predict outcomes in world politics'. On the contrary, 'other instruments such as

\footnotetext{
${ }^{25}$ Kennedy \& Lucas 2005, p323

${ }^{26}$ Coined by Moisés Naím, 2007 as a play on the 'CNN-effect' associated with the Gulf War.

27 Christensen, 2008; Andén-Papadopoulos (forthcoming)

${ }^{28}$ Galtung 1971, p99
} 
communications, organizational and institutional skills, and manipulation of interdependence have become important ... interdependence is often balanced differently in different spheres such as security, trade, and finance, 29 .

Communication strategies in Iraq can therefore be seen in terms of 'transposing' military and economic dominance into other spaces; bridging the realms of 'hard' and 'soft' power. American attitudes towards journalists offer an interesting example of how such strategies work in practice. Reporting from Iraq, based around journalists being 'embedded' with military personnel, has been criticised as a form of indirect (by presenting the war through the eyes and movements of troops) and direct (in the information permitted to be reported) censorship. Besides binding the survival of the journalists to the fate of the soldiers, it links the violent incursions of troops into the contested territorial spaces to the intrusion of lenses and news reporting, making them, in effect if not intention, part of the same invasion. Meanwhile, non-embedded journalists have been accidentally shot, Al-Jazeera offices in Baghdad and Kabul have been bombed, while more than a few unfriendly journalists have been excluded from CPA press conferences ${ }^{30}$. Since the only USG-approved alternative to embedded (or 'in bed' as they have been termed by some) journalists was military briefings, this indicates a sophisticated and holistic approach to managing perceptions of the war $^{31}$.

Taken together, these strategies can be seen as attempts to 'transpose' military force to the communicative sphere, thus binding material violence to the symbolic through the structural linking of military force to different aspects of media industries. It is from this perspective that I shall address and further discuss the RRMT media plan.

\section{The "Rapid Reaction Media Team"}

\section{Vision \& impact}

In January 2003, some two months before the war began, two Department of Defense agencies - one responsible for psychological operations, the other for covertly planning the war - issued a white paper putting forward the idea of a 'Rapid Reaction Media Team'

\footnotetext{
${ }^{29}$ Nye 1990, pp156-158; Jentleson 2007, p265

${ }^{30}$ Gopsill, 2004; Wilson 2006, p3; Sharp, 2003; Battle, 2007; van Ham 2003, pp431 \& 437; Svet, 2006.

Estimates set the death toll of journalists and their support staff at over 100.

${ }^{31}$ Lewis et al, 2003
} 
(RRMT) to set up an 'Iraqi Free Media' in the immediate onset of war $^{32}$. Its three major objectives were to 'inform the Iraqi public about USG/coalition intent and operations', 'stabilize Iraq (especially preventing the trifurcation of Iraq after hostilities)', and 'provide Iraqis hope for their future'. Clearly, such goals are not achievable solely through media, but it is nonetheless intriguing that so much weight was placed upon the potential for media to 'have a profound psychological and political impact on the Iraqi people'. This impact would be 'as if, after another day of deadly agit-prop, the North Korean people turned off their TVs at night, and turned them on in the morning to find the rich fare of South Korean TV spread before them as their very own'. The questions of whether it could or would be received 'as their very own', or how the accompanying violence would relate to the 'rich fare' provided by the network are, however, not addressed.

Two points can be made about this initial statement of purpose. First, the document is heavily entrenched in the position of the communicator, with little to no sense of the context of reception. The comparison with North Korea demonstrates a lack of cultural sensitivity, and an approach locked in a 'big picture' view of geopolitics rather than an emplaced demarcation of the Middle Eastern media geography. Furthermore, the plan lacks measurables. While the first objective could potentially be measured in terms of outputs (is the correct information being broadcasted?), the second, and to a lesser extent third are not sufficiently linked to the media exercise and lack clear means of evaluation. Two lessons about public diplomacy in a warfare context are clear here: tailor media objectives to the local and regional contexts; and develop objectives that can be evaluated.

\section{Programming strategies}

The 'digital broadcasting and publishing concept plan' included a list of USG approved programming that would facilitate these goals. This included: a 'de-Bathification program', the re-telling of Iraq's recent history from an objective (ie, American) perspective, a 'democracy series', and Hollywood, news, and sports. Some of the programming was devolved to various American private sources, some was to be produced by USG trained and approved Iraqi staff under supervision (referred to as 'the face' of the operation). Despite the stated intention of avoiding dividing Iraq into three, news was to be tailored specifically to Shia, Sunni, and Kurd audiences. The 'media experts team' would comprise during the

\footnotetext{
${ }^{32}$ U.S. Department of Defense et al, 2003
} 
warfare phase of vetted US, UK, and Iraqi citizens, with 'professional US-trained Iraqi media teams immediately in place to portray a new Iraq (by Iraqis for Iraqis)' after cessation of hostilities $^{33}$. Broadcasting strategies seem to have been linked to an Information Operations approach based around centralised control, with some initial devolution of power to military contractors with the eventual aim of handing over production (but not control) to 'hand picked' Iraqis.

There are some interesting spatio-temporal strategies at work here. By 'projecting' time into space, the RRMT views history as a construction which can simply be switched with alternative histories to suit the conditions of the day ${ }^{34}$. The military control over Iraqi media space allows for control over representations of historical temporalities. Use of 'vetted' UK and US Iraqis as the 'face' of the organisation indicates that hybrid ethno-cultures were simply another tool in the arsenal; 'by Iraqis for Iraqis' involves the strategic deployment of UK and US-vetted perspectives wrapped in the face-value symbolism of Iraqi skins. Furthermore, domination of news flows was supposed to control the representation of information regarding the occupation. By addressing different groups differently, Iraqi media space was to be controlled both spatially ('divide and rule') and in different temporalities in a manner that transposed military strength into the discursive sphere. We could perhaps begin to speak, from this basis, of a symbolic violence complimentary to the physical in a manner more direct than Nye's twin concepts of soft and hard power ${ }^{35}$.

\section{Outcomes}

The contract was eventually awarded (without due procedure) to a defence contractor with no media experience, Scientific Applications International Corporation (SAIC) on March 11 2003, nine days before the war began. SAIC began broadcasting radio in April, with television and newspaper publications following in May. The Iraqi Media Network (IMN) was formally declared an interim entity by the Coalition Provisional Authority (CPA) in June, thereby replacing Iraq's Information Ministry and claiming its staff, equipment, and facilities. By this stage however, issues of poor planning and organisation came to a head in a series of strikes and firings (over 5,000 staff were made unemployed), while public perception in Iraq

\footnotetext{
${ }^{33}$ Battle, 2007; U.S. Department of Defense $e t$ al, 2003. References to UK staff suggest little more than token inclusion.

${ }^{34}$ Lefebvre 1981/2008, p133

${ }^{35}$ Nye, 1990
} 
was that the network was the propaganda wing of the USG. This was not helped by the frequent broadcasts of unedited official statements by US Administrator Paul Bremner (in which he referred to Saddam as 'the evil one'), CPA news conferences, and the broadcast of relatively few Hollywood entertainment products. The latter was due to poor planning in securing broadcasting rights, which underscores the contradictions and complexities of stateprivate relations, and the difficulty of producing a news and entertainment flow in a hostile space with little preparation time or industry experience. Within six months, polls were suggesting that as few as one in ten Iraqis watched the network, and the CPA hired J. Walter Thompson to mount a PR campaign to assert the credibility of the renamed Iraqia Network.

A second US-led satellite news and entertainment network, al-Hurrah ('the free ones') began broadcasting to Iraq in April 2004, with the stated aim of competing with 'the hateful propaganda' (Bush's words) of the two most popular new outlets in the region, Al-Jazeera and Al-Arabiya. The station was based in Virginia, centralising and distancing the production process from Iraq, with President Bush ill-advisedly making the inaugural broadcast. Far from fulfilling the original RRMT objective of creating a station 'by Iraqis for Iraqis', this reflected and accentuated the problems of the parallel military occupation. Early Arab newspaper editorials were 'universally contemptuous' of what was considered a further example of American propaganda ${ }^{36}$. In an environment of over 200 new publications, mostly sponsored by religious and political groups and aimed at specific audiences, such strategies seem illequipped to offer a credible representation of a unified Iraqi national space. Ironically, it is the 5,000 staff fired from the IMN that fuelled the growth in independent Iraqi publishing, while political and religious interest groups, sensing formalised roles in the new democracy, have funded the promotion of sectarian perspectives in local and regional media. The US attempted to adapt to this but could only do so through coercive means - in December 2005 and March 2006 the Pentagon admitted that it was both feeding positive news stories to the Iraqi press, and secretly paying newspapers to carry them ${ }^{37}$.

\footnotetext{
${ }^{36}$ Snow \& Taylor 2006, pp392-394; Battle, 2007; North, 2003; Cotts, 2003; Reporters sans frontiers (http://www.rsf.org/article.php3?id_article=7583). Ambassador William Rugh's statement to the US Senate backs up the view that the station was unlikely to ever become a credible news source in the region; see Rugh, 2004.

${ }^{37}$ North, 2003; Cochrane, 2006
} 
A 2008 independent study of Al-Hurra commissioned by the Broadcasting Board of Governors (BBG) found little to be positive about. The network was struggling to live up to the provisions of objectivity laid out by the International Broadcasting Act of 1994, and nor was it competing effectively in the Arab news marketplace. Content analysis confirmed the perceived pro-US bias expressed in the focus groups, leading to the conclusion that Al-Hurra was out of touch with its audience ${ }^{38}$. Other studies confirm these results. For example, polls of the opinions of around 400 students in Kuwait, UAE, Jordan, Palestine, and Morocco found no correlation between frequency of use of US networks al-Hurrah and Radio Sawa and favourable opinions of US foreign policy. Rather, many respondents who viewed the channels regularly felt negatively about US foreign policy on the grounds that it spoiled the entertainment by tainting it with propaganda ${ }^{39}$.

\section{The RRMT: physical, structural \& symbolic violence}

In conclusion, the RRMT encapsulates a number of coordinated strategies designed to help USG and the coalition 'produce' a new Iraq. From the platform of military (and economic) superiority, the US media plan structurally separates the nation into three; inserts history into the space; and attempts to steer news and informational flows both inside and outside the nation to suit its interests. While acting on the one hand as a public diplomacy outlet capable of providing the new Iraq with a public sphere, military Information Operations concerns were clearly dominant, and contradictory. Military public diplomacy is an oxymoron, and the selection of terms in academic articles and national strategies needs to be clear on this.

As a compliment to military strategy, media are important forces in struggles over meaning and identity. The interactions between physical violence and symbolic violence - as well as national interests and private industries - are essential for making sense of contemporary media roles, as well as for making sense of contemporary warfare. However, what remains clear is that strategies which seek to hermetically seal a national space, to treat it as a totally controlled zone, are out of touch with how transnational media function in the twenty-first century. The RRMT's vision of Iraq was neither measurable nor realistic, lacked an understanding of the media context in Iraq and the region, and had little interest for the

\footnotetext{
${ }^{38}$ USC Center on Public Diplomacy at the Annenberg School, 2008

39 el-Nawawy, 2006
} 
context of reception. All indications are that this fundamental misunderstanding persists in Al-Hurra broadcasts to this very day.

The RRMT plan demonstrates the problems and contradictions involved in 'transposing' power across spaces in which interdependence is balanced unevenly and unpredictably, and can be challenged in different ways. Such contradictions are central to explaining the difficulties of 'producing' an abstract discursive space capable of informing, stabilizing, and providing hope for an occupied nation ${ }^{40}$. Possible solutions may perhaps be found in the careful delineation of public diplomacy and IO functions so that the public sphere is provided by one set of actors and the military propaganda by another. The first might benefit from being thinking more about the context of reception and concentrating on those diverse interests - such as improving its relationship with existing regional news networks, engaging with and listening to broad audiences, and patiently advocating the US position with sensitivity to other views even when the framing of the debate is critical (after all, the debate was widely critical in the west). The military side of operations may be better focused on providing timely information, correcting misinformation, and advocating the US military's perspective. While force may still be transposed to the symbolic sphere, it seems clear from the RRMT experience that the weapons need to be more subtle, more realistic, and more differentiated.

\footnotetext{
${ }^{40}$ U.S. Department of Defence et al, 2003
} 


\section{References}

Agnew, John \& Corbridge, Stuart (1995) Mastering Space: Hegemony, Territory and International Political Economy. London: Routledge

Altheide, David L. \& Grimes, Jennifer N. (2005) War Programming: The Propaganda Project and the Iraq War, pp617-643 of The Sociological Quarterly Vol.46. Midwest Sociological Society

Andén-Papadopoulos, Kari (forthcoming) Body Horror on the Internet. Journal of Media, Culture \& Society

Arrighi, Giovanni (2005) Hegemony Unravelling-1, pp 23-80 of New Left Review 32, MarApr 2005

Battle, Joyce (ed) (2007) Iraq: The Media War Plan. National Security Archive Electronic Briefing Book No.219. Available at http://www.gwu.edu/ nsarchiv/NSAEBB/index.html

Baudrillard, Jean (1995) The Gulf War Did Not Take Place (trans Paul Patton). Sydney: Power Publications

Brown, Robin (2003) Spinning the War: Political Communications, Information Operations and Public Diplomacy in the War on Terrorism, pp87-100 of Thussu, Daya Kishan \& Freedman, Des (eds) (2003) War and the Media: Reporting Conflict 24/7. London: SAGE Publications

Business for Diplomatic Action (2007) America's Role in the World: A Business Perspective on Public Diplomacy. BDA

Cameron, Angus \& Palan, Ronen (1999) The Imagined Economy: Mapping Transformations in the Contemporary State, pp165-184 of Brenner, Neil; Jessop, Bob; Jones, Martin; Macleod, Gordon (eds) (2003) State/Space: A Reader. Oxford: Blackwell

Christensen, Christian (2008) Uploading Dissonance: YouTube and the US occupation of Iraq, pp155-175 of Media, War \& Conflict Vol 1(2)

Clark, Andrew M. \& Christie, Thomas B. (2005) Ready ... Ready ... Drop! A Content Analysis of Coalition Leaflets Used in the Iraq War, pp141-154 of Gazette: The International Journal for Communication Studies Vol 67(2). SAGE Publications

Cochrane, Paul (2006) The 'Lebanonization' of the Iraqi Media: An Overview of Iraq's Television Landscape. TBS Journal 16, 2006

Cotts, Cynthia (2003) Iraq: Is Anyone Watching the Iraqi Media Network? Village Voice, New York, November 122003 
Couldry, Nick \& McCarthy, Anna (eds) (2004) MediaSpace: Place, Scale and Culture in a Media Age. London: Routledge

Defense Science Board (2004) Report of the Defense Science Board on Strategic Communication. Department of Defense

Epstein, Susan B. (2006) U.S. Public Diplomacy: Background and the 9/11 Commission Recommendations (RL32607). The Library of Congress: Congressional Research Service (CRS)

Falkheimer, Jesper \& Jansson, André (eds) (2006) Geographies of Communication. Nordicom Fisher, Ali \& Bröckerhoff, Aurélie (2008) Options for Influence: Global campaigns of persuasion in the new worlds of public diplomacy. London: 'Counterpoint - the cultural relations think-tank of the British Council'

Friedman, Herbert A. (2003) PSYOP in Operation Iraqi Freedom, pp4-10 of Perspectives: Journal of the Psychological Operations Association, Volume 15, Number 2 Galtung, Johan (1971) A Structural Theory of Imperialism, pp81-117 of Journal of Peace Research 1971; 8

Gopsill, Tim (2004) Target the Media, pp251-261 of Miller, David (ed) Tell Me Lies: Propaganda and Media Distortion in the Attack on Iraq. London: Pluto Press

Harvey, David (1990) The Condition of Postmodernity. Oxford: Blackwell

Harvey, David (2003) The New Imperialism. Oxford

Jentleson, Bruce W. (2007) American Foreign Policy: The Dynamics of Choice in the $21^{\text {st }}$ Century, third edition. London: WW Norton \& Company

Kendrick, Alice \& Fullerton, Jami A. (2005) Advertising as Public Diplomacy: Attitude Changes Among International Audiences, pp297-311 Journal of Advertising Research Vol.44(3)

Kennedy, Liam \& Lucas, Scott (2005) Enduring Freedom: Public Diplomacy and U.S. Foreign Policy, pp309-333 of American Quarterly Vol.57(2)

Lefebvre, Henri (1961/2008) Critique of Everyday Life Volume 2 (trans John Moore). London: Verso

Lefebvre, Henri (1968/1969) The Explosion: Marxism and the French Revolution (trans Alfred Ehrenfeld). New York: Monthly Review Press

Lefebvre, Henri (1974/1991) The Production of Space (trans Donald Nicholson-Smith). Blackwell Publishing 
Lefebvre, Henri (1981/2008) Critique of Everyday Life Volume 3: from Modernity to Modernism (trans Gregory Elliott). London: Verso

Mann, Michael (1997) Has Globalization Ended the Rise and Rise of the Nation-State?, pp135-146 of Held, David \& McGrew, Anthony (eds) (2003) The Global Transformations Reader, Second Edition. Cambridge: Polity Press

McCormick, James M. (2005) American Foreign Policy \& Process, Fourth Edition. Thompson Wadsworth

Miller, David (ed) (2004) Tell Me Lies: Propaganda and Media Distortion in the Attack on Iraq. London: Pluto Press

Naím, Moisés (2007) The YouTube Effect, pp103-104 of Foreign Policy January/February 2007

Nakamura, Kennon H. \& Epstein, Susan B. (2007) Diplomacy for the $21^{\text {st }}$ Century: Transformational Diplomacy (RL34141). The Library of Congress: Congressional Research Service (CRS)

El-Nawawy, Mohammed (2006) US public diplomacy in the Arab world: the news credibility of Radio Sawa and Television Alhurra in five countries, pp183-203 of Global Media and Communication 2006, 2

North, Don (2003) Iraq: One Newsman's Take On How Things Went Wrong. Television Week, December 152003

Nye, Joseph S. Jr. (1990) Soft Power, pp152-171 of Foreign Policy, no. 80, Fall 1990 PCC (2007) U.S. National Strategy for Public Diplomacy and Strategic Communication.

Strategic Communication and Public Diplomacy Policy Coordinating Committee (PCC)

Rugh, William A. (2004) Statement to the U.S. Senate Foreign Relations Committee, Subcommittee on International Relations and Terrorism, April 292004.

Sharp, Jeremy M. (2003) The Al-Jazeera News Network: Opportunity or Challenge for U.S. Foreign Policy in the Middle East? (RL31889). The Library of Congress:

Congressional Research Service (CRS)

Shohat, Ella \& Stam, Robert (1994) Unthinking Eurocentrism: Multiculturalism \& the Media. London \& New York: Routledge

Snow, Nancy \& Taylor, Phil (2006) The Revival of the Propaganda State: US Propaganda at Home and Abroad since 9/11, pp389-407 of The International Communication Gazette Vol.68(5-6). SAGE Publications 
Svet, Oleg (2006) Public Diplomacy: War by Other Means. Electronic edition available at http://fletcher.tufts.edu/jebsencenter/pdfs/Draft_November_5_2006_SS.pdf

Taylor, Phil (2003) 'We Know Where You Are': Psychological Operations Media During

Enduring Freedom, pp101-114 of Thussu, Daya Kishan \& Freedman, Des (eds) (2003) War and the Media: Reporting Conflict 24/7. London: SAGE Publications

United States Department of Defense, Office of the Assistant Secretary for Special Operations and Low-Intensity Conflict; and Office of the Assistant Secretary, Near East and South Asian Affairs (Special Plans) (2003) White Paper: 'Rapid Reaction Media Team' Concept. Declassified through the Freedom of Information Act. National Security Archive: part of Battle, 2007. Available at http://www.gwu.edu/ nsarchiv/NSAEBB/index.html

USC Center on Public Diplomacy at the Annenberg School (2008) An Evaluation of Alhurra Television Programming. Los Angeles: Figueroa Press

Van Ham, Peter (2003) War, Lies, and Videotape: Public Diplomacy and the USA's War on Terrorism, pp427-444 of Security Dialogue Vol.34(4). SAGE Publications

Wilson, Clay (2006) Information Operations and Cyberwar: Capabilities and Related Policy Issues (RL31787). The Library of Congress: Congressional Research Service (CRS) 